\title{
Taide ja henkilöstökoulutus
}

TEIJA FONTELL

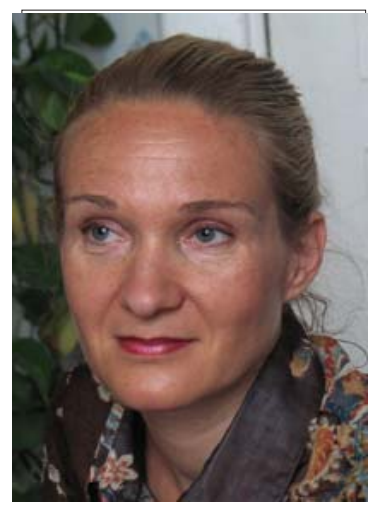

\author{
Tässä artikkelissa käsittelen organisaatioiden ja yritysten kehittä- \\ mismahdollisuuksia kehittämieni taidepainotteisten ja kuvallisten \\ henkilöstökoulutusmenetelmien avulla.
}

Kansainvälistyminen, teknistyminen, organisaatioiden verkostoituminen ja rakenteiden madaltuminen sekä muuttuvat työn sisällöt moninaistavat työyhteisöjen ja organisaatioiden toimintaa. Organisaatioissa olevat käytänteet ja niiden taustalla olevat kulttuuriset merkitysjärjestelmät sekä yksilö työyhteisön jäsenenä ovat joutunut yhä useammin asettumaan uudenlaiseen vuoropuheluun muutoksen kanssa (Juuti \& Lindström. 1995). Muutokset voidaan nähdä myös laajempina prosesseina, jotka heijastelevat organisaation ulkoisiin ja sisäisiin ajattelutapoihin, toimintamalleihin, tehtäviin sekä ihmisten työnkuviin.

Yhä tärkeämmiksi tekijöiksi organisaatioiden kehittämisessä ovat nousset vuorovaikutussuhteet, yhteistyötaidot, tiedon hankinta- ja käyttötaidot sekä teknologian hyödyntäminen. Johdon ja esimiesten on osattava tunnistaa, organisoida ja suunnitella resurssien hallintaa ja heidän on kyettävä ottamaan huomioon se, kuinka organisaatioissa vaikuttavat ns. henkilökemiat, ryhmäprosessit, viestintä, roolit ja valtasuhteet.

Usein todetaan kuinka organisaatio, joka rakentuu oppivan organisaation periaatteille, ”osaa käyttää kaikkien yksilöiden ja ryhmien koko oppimiskykyä yhteisen tavoitteiden saavuttamiseksi ja kykenee luomaan jatkuvaan oppimiseen ja kehittämiseen kannustavan ilmapiirin” (Toskala. 2000). Lisäksi tämän kaltainen organisaatio kykenee siirtämään ja muuntamaan käyttäytymistään uuden tiedon ja näkemyksen mukaan, mikä helpottaa asioiden välisten suhteiden ja muutosten jäsentämistä kokonaisvaltaisesti.

Organisaation kehitystyössä on kuitenkin aina syytä muistaa, että organisaatio itsessään ei opi. Se oppii ja kehittyy vain oppivien yksilöidensä kautta, jolloin vanhojen ajattelutapojen ja tietojen hylkääminen on yhtä tärkeää kuin uuden oppiminen. Organisaation kehittäminen edellyttää usein sosiaalisten rakenteiden, töiden järjestelyjen ja sisältöjen tarkastelua ja näissä tehtäviä mahdollisia muutoksia. On kuitenkin otettava huomioon, että muutokset yksinään saattavat tehdä toimenpiteistä liian ulkokohtaisia ja pinnallisia.

Organisaation pysyvämpien muutosten taustalla tulisikin olla yhteisöä rakentavaa syvempää ajattelun muutosta sekä toiminnan jatkuvaa arviointia. Se puolestaan vaatii taitoa, rohkeutta ja herkkyyttä epäillä tuttua ja turvallista. Yhtenä oleellisena lähtökohtana kaikelle kehitystyölle voidaankin pitää avointa keskustelua ja yhteisen kielen rakentamista. Tätä kautta on mahdollisuuksia löytää yhtenevät käsitykset asioista. Useat organisaatioteoriat painottavatkin organisaatioita sosiaalisesti konstruoituina todellisuuksina ja toisaalta kielellisinä konstruktioina.

Organisaatiokulttuuria on myös määritelty "säännönmukaiseksi käyttäytymiseksi” kuten erilaisiksi normeiksi, arvoiksi, kielen ja hyvän käytöksen rituaaleiksi ja pelisäännöiksi organisaatiossa selviytymiseksi. Jopa tunnelmaa tai ilmapiiriä, jolla jäsenet ovat vuorovaikutuksessa toisten- 
sa tai asiakkaiden tai muiden ulkopuolisten kanssa, on saatettu kutsua nimellä organisaation kulttuuri. Tutkija Edgar H. Scheinin mielestä (Scheinin 1991) nämä tekijät eivät kuitenkaan ole kaikkein oleellisimmat puhuttaessa organisaation kulttuurista. Scheinin mielestä kulttuuri tarkoittaa "perusoletusten mallia”, jonka jokin ryhmä on keksinyt, löytänyt tai kehittänyt oppiessaan käsittelemään ulkoiseen sopeutumiseen tai sisäiseen yhdentymiseen liittyviä ongelmiaan.

Organisaatioiden muutospyrkimyksissä on yhä enenevässä määrin pyritty hahmottamaan yhteisön oman historian tuloksena syntynyttä syvärakennetta. Tämä rakenne ilmenee usein ns. symbolisina kenttinä: yhteisön sisäisissä tarinoissa, rituaaleissa, perinteissä, arvoissa yms.

Henkilöstökoulutuksessa oleellista on käynnistää tämän aikojen saatossa syntyneen kulttuurin syvärakenteen muutosprosessi. Tällöin organisaation sisäisen symbolisen kentän ominaispiirteet on pyrittävä ymmärtämään ja tulkitsemaan sekä "mytologisoimaan uudelleen" (Juuti \& Lindström 1995). Tämän muutostyön aikana yhteisöllä on mahdollisuus rakentaa uutta kuvaa itsestä ja koko organisaatiosta ja sen verkostosta, kilpailijoista, asiakkaista ja niistä tulevaisuuden haasteista, joihin tulee reagoida uudella tavalla.

Uudelleen mytologisoinnilla pyritään paljastamaan myös sosiaalisen käyttäytymisen taustalla olevaa ajattelutapojen rikkautta, joka onnistuu parhaiten tuotaessa organisaatioissa työskentelevien ihmisten tietoisuuteen vertauskuvien avulla heidän oma toimintansa, heidän käyttämänsä kieli ja siihen liittyvä olemisen tapa.

Kulttuurin symbolisen kentän eli kulttuurin syvärakenteen ymmärtämiseen tähtäävää tutkimusta voidaan pitää uudelleenmytologisoinnin ensimmäisenä vaiheena. Toisessa vaiheessa myytit pyritään kytkemään niihin tilanteisiin, joissa ne ovat syntyneet. Näin organisaation jäsenet voivat hahmottaa niitä monensuuntaisia prosesseja, jotka liittyvät heidän omaksumiensa ja itsestään selvinä pitämiensä toiminta- ja ajattelutapojen taustalle. Uudelleenmytologisoinnin kolmannessa vaiheessa organisaation jäsenet pyritään sitouttamaan uusiin myytteihin ja tarinoihin. (Juuti \& Lindström 1995).

\section{Taide ja todellisuus}

Yhteiskunnassamme sana taide on viime aikoina laajentunut käsittämään yhä useampia toiminnan alueita. Siitä on tullut kuvainnollinen sana hahmottaa eri taitavuuden ja mahdollisuuksien alueita. Samalla se toimii vastakohtana tavoitteille, joissa pyritään alistamaan etukäteen monimuotoisuus yhden tulkinnan alueelle. "Taide ja taiteen tulkinnallinen huomio on suuntautunut merkitysten luomisprosesseihin ja niihin mekanismeihin, strategioihin, tapahtumiin, joilla merkitykset syntyvät”, toteaa taiteen tutkija Mika Karhu. Karhun mukaan nykytaide on tila, jonka sisälle voidaan tuoda monenlaisia tulkinnan tapoja ja visuaalisia toiminnan alueita. Taide on laajasti yhteydessä ihmisen elämän eri alueisiin ja muodostaa näin sen merkityksien taustan, jonne taiteen tulkinnallinen sisältö voidaan sijoittaa. Aikamme taidekuvaan kuuluvat myös eri tieteenaloja yhdistävät näkökulmat jotka tuottavat uutta tietoa ja ymmärrystä taiteesta myös sosiaalisena konstruktiona. (Kar$h u$ 2003). Taiteellisen toiminnan ja uuden kehittymisen näkökulmasta keskeiseksi tekijäksi on myös taidemaailmassa noussut vuorovaikutteisuus, joka toimiessaan rikastuttaa kaikkia alueita ja toimijoita.

Nykyisissä taiteen tutkimuksissa painotetaan usein vastaanottajan yksilöllisiä tulkintoja. Tällöin taideteos on se, minkä vastaanottaja mielessään siitä konstruoi, miten hän sitä tulkitsee tai rakentaa sille omia merkityksiä. Se, millaisena todellisuuden kukin näkeekään, on yhteydessä taiteen vastaanottajan omakohtaiseen taustaan ja persoonalliseen tulkintaan. Näin vastaanottaja myös luo omalla tulkinnallaan ja merkityksenannollaan taidetta. On myös muistettava, että ihmisten tapa ajatella ei suinkaan aina ole pelkästään henkilökohtaista tulkintaa ympäröivästä maailmasta, vaan usein se kertoo myös laajemmin kulttuurisista rakenteista, normeista ja tavoista. Tällöin taiteen vuoropuhelusta todellisuuden kanssa muodostuu tulkinnan ja merkityksenannon moniäänistä ja toinen toisiinsa heijastelevaa vuoropuhelua.

Taiteelliseen työskentelyyn, joko omakohtaisena taiteellisena tuottamisena tai taiteen kokemuksellisena kohtaamisena, liittyy aina tekijän henkilökohtainen prosessointi. Tämän prosessoinnin myötä avautuu uusien oivallusten kirjo, joka luo uuden oppimisen mahdollisuuksia ja olemassa olevien asioiden tarkastelua toisin.

Taidekasvatuksen yksi oleellisimmista tehtävistä on taidetta ja taiteellisia prosesseja koskevan tiedon muuntaminen pedagogiseksi tiedoksi ja tarjota näin ihmiselle mahdollisuuksia sekä luoda 
uutta tietämistä ja ymmärrystä että konstruoida jo olemassa olevaa. Taidepedagogiikan emeritusprofessori Inkeri Sava (Sava 2005) on tutkimuksissaan nostanut esiin näkökulman taiteen mahdollisuuksista tuottaa syvimmillään toisenlaista tietoa, "siitä mikä ei ole ilmeistä ja pintarakenteissa näkyvää”. Savan näkemyksen mukaan taiteelliselle toiminnalle tärkeät yksilölliset ja kulttuuriset prosessit, ihmisten myyttiset tarinat ja kollektiiviset alitajuiset virrat ovat alkaneet kiinnostaa myös laajempina epistemologisina kysymyksinä - tietämisen prosesseina - eivät pelkästään irrationaalisina, mielen mystiikkaan liittyvinä näkemyksinä. Tämän teesin mukaan syntyy selkeä yhteys yrityksissä harjoitettavaan organisaation kehittämiseen.

Joitain kokeiluja taiteellisten menetelmien käytöstä yrityselämän kontekstissa meillä toki on. Erityisesti työhyvinvoinnin kehittämisessä on kokeiltu muun muassa tanssin ja valokuvauksen käyttöä. Näistä esimerkeistä on saatu positiivista palautetta ja ne ovatkin toimineet kannustavina esikuvina tarjoten hyviä ja kehittämiskelpoisia malleja.

Saksassa elinkeinoelämässä on käytetty erilaisia taiteellisia harjoituksia sosiaalisten vuorovaikutustaitojen kehittämisessä jo pitkään. Aiheesta on myös tehty tutkimuksia, joissa on todettu että erilaisilla taiteellisilla harjoitteilla on selkeästi voitu tukea työntekijöiden toimintakykyä, osaamista ja motivaatiota. (von Brandenburg 2006). Yhdeksi tärkeäksi tekijäksi taiteen hyödyntämisessä on nähty mielikuvituksen ja luovuuden kehittäminen. Työkyvyn kannalta kokemuksellisen oppimisen on todettu tukevan persoonallista työhyvinvointia edistämällä joustavuutta ja stressin hallintakykyä uusissa työtilanteissa. Myös taideterapiatyöskentelyä on Saksassa toteutettu rohkaisevin tuloksin.

\section{Omat kokemukseni taiteen käyttämi- sestä henkilöstökouluttajan työssä}

Oma työskentelyni yritysten ja työyhteisöjen henkilöstökouluttajana on rakentunut taidekoulutukseni ja toistakymmentä vuotta jatkuneen taideopettajuuden lisäksi hankkimani johtajuuskoulutuksen, henkilöstökouluttajan ja aikuiskasvatustieteen opintojen pohjalta. Yleensä pitämieni koulutusten sisällölliset haasteet ja päämäärät nousevat kyseisten työyhteisöjen tai organisaatioiden omista tarpeista. Olen ohjannut prosesseja joissa on työstetty yrityksen arvoja tai "purettu” organisaation arvot työyhteisön käytännön työn tekemisen tasolle. Kanssani on rakennettu henkilöstön osaamiskartoitusta kuvaava "puu”, jolloin työyhteisön yksilöllinen ja yhteisöllinen osaaminen on työstetty näkyväksi. Lisäksi olen ohjannut koulutuksia, joissa on toteutettu yrityksen kuvallinen SWOT-analyysi, jonka myötä yrityksen strategia on rakennettu uusiksi.

Koulutuksissani sovellan aineksia niin taideterapiasta, yhteisötaiteesta kuin kouluttajien "konsultoivasta otteesta”. Lähtökohtaisesti toimintaani ohjaa näkemys hermeneuttisen mallin mukaisesta "tuttuuden ja vierauden välissä” olevasta ymmärryksen, tulkinnan ja uusien merkitysten kudelmasta. Se, tapahtuuko toiminta "itse taidetta luomalla” vai taidetta tulkitsemalla, ei tämän hetkisen ymmärrykseni valossa ole oleellisinta. Mielestäni oleellisinta on se yksilöllinen dialogi, joka syntyy vastaanottajan omakohtaisten tulkintojen ja merkitystenantojen välillä, sekä se yhteisöllinen kokemus ja dialogi joka rakentuu kaikkien tapahtumaan osallistuneiden kesken. Näkemykseni mukaan juuri tämän prosessin myötä voi tapahtua ihmisten, samoin kuin organisaatioidenkin tietoisuuden kasvua, sellaista kasvua, joka syntyy ja rakentuu sosiaalistumisen, vuorovaikutuksen sekä yhteisten kokemusten myötä.

Mielestäni organisaatioiden kulttuurin kehittyminen entistä kypsemmälle tasolle vaatii uudenlaista kuuntelemista, kohtaamista ja moninaisuuden hyväksymistä. Tämän näkyväksi tekemisessä, prosessoinnissa ja uuden tiedon ja osaamisen synnyttämisessä, koen taidekasvatuksen perinteisellä osaamisella olevan paljon annettavaa. Sillä elämyksellinen ja kokemuksellinen taidetoiminta osana ihmisten arkipäiväistä työtä voi samalla muuttaa myös työyhteisöä jäsenilleen merkitykselliseksi.

Työhyvinvointi ja siihen vaikuttavat tekijät, kuten tiedonkulku, palautteen antaminen ja saaminen sekä erilaisuuden näkeminen rikastavana tekijänä ovat työyhteisöissä selvästi niitä alueita joita työstettäessä on mielestäni kovin luontevaa käyttää erilaisia taiteen tekemisen ja kokemisen menetelmiä.

Itse olen työhyvinvointiin liittyvissä koulutuksissa käyttänyt usein työskentelyä saven kanssa sekä koko työyhteisön kanssa tehtävää yhteismaalausta. Saven kanssa työskentely voi tarjota hyvin meditatiivisen hetken ja avata keskustelua tasoille, jolla harvoin liikutaan. Yhteismaalaus 
puolestaan saattaa paljastaa työyhteisöstä totuudellisia asioita hyvin konkreettisesti. Esimerkiksi työntekijän oman reviirin tarpeen, vastuun ottamisen yhteisistä asioista, yhteistyön mekanismeja, huumorin, innostamisen ja organisoinnin, ne ovat aiheita jotka näkyvät hyvin selvästi yhteismaalaustilanteissa ja silloin niitä on myös helppo yhteisesti käsitellä. Mielestäni tämä luova yhteinen työskentely ja sen aikana syntyvä keskustelu on ennen kaikkea yhteistä prosessointia. Sen myötä opitaan toisilta, välitetään tietotaitoa, arvoja, tulevaisuuden suuntautumista, ideoita ja rakennetaan työyhteisöä vahvistamalla yhteenkuuluvuuden ja yhteisen kommunikaation ja kohtaamisen taitoja.

\section{Yhteismaalaus: aiheena oma työyhteisö}

Jos vertaillaan työhyvinvoinnin käsittelyä taiteellisten harjoitteiden avulla ja vastaavasti luentotyyppisen keskustelun myötä, niin jälkimmäinen suo osallistujille myös mahdollisuuden pysytellä syrjässä. Tällöin käsiteltäviä asioita voidaan todeta ja niiden tärkeyttä korostaa, mutta mikään ei takaa että ne syvemmässä mielessä koskettaisivat osallistujia. Usein luentotyyppisessä tilanteessa "ongelmat" koskevat toisia ihmisiä, tai tuntuvat kuulijasta yleistyksiltä. Taiteellisten harjoitteiden kanssa tilanne on toinen. Tekeminen on jo itsessään fyysistä ja tulee samalla ihmistä itseään lähemmäksi. Omaa työhyvinvointia prosessoidessaan käytännön tasolla ihminen joutuu kysymään ja kuuntelemaan itseään ja omaa olemistaan, ei vain sitä mitä ulkopuolinen luennoitsija kertoo.

Työskennellessä kuvien, värien ja muotojen kanssa liikutaan alitajunnan ja symbolisten merkitysten alueilla, jolloin niin henkilökohtaisten kuin yhteisöllisten merkitysrakenteiden purkaminen ja uusien luominen tapahtuu. Esimerkiksi jo sana visio eli tulevaisuuden suunnitelma, näkymä, herättää ajatuksen kuvallisesta muodosta. Usein yrityksen vision rakentamisen taustalla onkin lukematon määrä erilaisia mielikuvia, joiden avulla on hahmoteltu erilaisia strategisia ratkaisuja ja niiden vaikutuksia.

Tiedon analogisessa prosessoinnissa mielikuvilla on tärkeä tehtävä, sillä niiden avulla voidaan nopeasti havaita yhtäläisyyksiä ja eroavaisuuksia. Koska mielikuviin yhdistyvät myös kohteiden herättämät tunteet, analoginen prosessointi käy nopeammin kuin loogiseen ajatteluun kuuluva käsitteellinen vertailu (Toskala 2000). Mutta mitä tapahtuu, kun mielikuvat ovat konkreettisia taidekuvia; piirustuksia, valokuvia, maalauksia tai veistoksia? Syntyykö näin kenties perustellumpia tai syvempiä näkemyksiä? Oman kokemukseni mukaan näin tapahtuu.

Esimerkkinä tämänkaltaisesta kuvallisesta työskentelystä voin mainita erään pk-yrityksen työntekijöiden ja toimitusjohtajan kanssa toteuttamamme kuvallisen SWOT:in (heikkoudet, vahvuudet, mahdollisuudet ja uhat). Työskentelymme lopussa avasimme rakentamamme kuvakollaasin myös sanalliseen muotoon jolloin siitä tuli yrityksen hallituksen strategiseen suunnittelun työkalu. Työstäessämme kuvallista SWOT:ia työyhteisön jäsenet valitsivat suuresta taidekuvien valikoimasta kuvia jotka heidän mielestä sopivat parhaiten kuhunkin SWOT:in nelikentän osaalueeseen. Jokainen valittu kuva käytiin yhdessä keskustellen läpi. Näin kuvat sekä helpottivat että nopeuttivat yhteistä kommunikointia. Niiden myötä keskustelussa liikuttiin vaivatta sekä abstraktilla että konkreettisella tasolla ja kuvien avulla oli mahdollista nopeasti ja selkeästi rajata epäoleellisuuksia tai epäkelpoja ideoita pois. Tämä teki työskentelystä hyvin intensiivisen.

Merkityksellisenä kuvien kautta työskentelyssä koen että se aktivoi osallistujien oman mielikuvituksen käyttöä ja auttaa ihmisiä hahmottamaan käsiteltävissä olevan kokonaisuuden paremmin. Sitoutuminen yhteiseen työskentelyyn paranee ja se heijastelee laajemminkin ihmisten sitoutumiseen koulutuksessa rakennettuihin yhteisiin päämääriin. Työskentely kuvien kautta laukaisi yleensä osallistujissa iloa ja huumoria. Useimmiten se myös tempaisee työyhteisön hiljaisimmatkin jäsenet mukaan yhteiseen työskentelyyn ja ideointiin. Helpoista ja itsestään selvistä vaihtoehtojen näkemisestä mennään kohti "syvempiä kerroksia”, sinne missä uudet ja luovat ratkaisut muhivat.

Erilaisten työyhteisöissä tapahtuneiden taideorientoituneiden työskentelyjen myötä olen voinut todeta kuinka taidetta hyödyntävällä työskentelyllä on mahdollisuuksia toimia eräänlaisena kommunikatiivisena "siltana" ihmisten ja heidän ymmärtämysmaailmojen välillä. Tämä voi auttaa ihmisiä näkemään olemassa olevaa uudella tavalla, minkä olen todennut erittäin hyväksi erityisesti työyhteisöissä jotka elävät muutospaineiden alla. Taiteellisen työskentelyn avulla on mahdollisuuksia purkaa auki vallitsevaa organisaatiokulttuuria ja päästä kiinni syvällä vaikuttaviin 


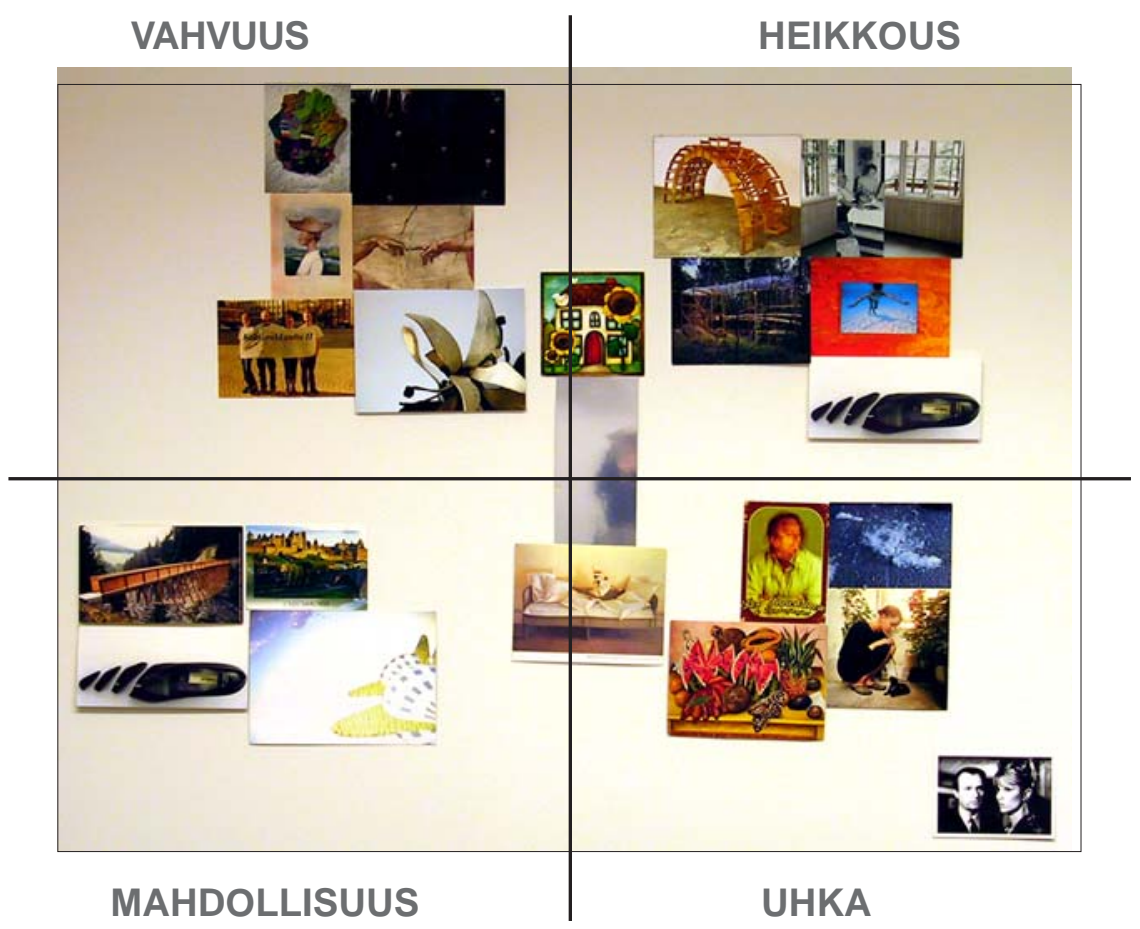

asenteisiin ja tottumuksiin. Mielikuvitusta hyödyntävä työskentely avaa mahdollisuuksia luoda ja konstruoida uudenlaisia kuvia, joko oikeita - tai mielikuvia. Taide eri ilmenemismuodoissa voi näyttää tulevaisuuden näkymiä niin yksittäiselle ihmiselle, työyhteisölle kuin jopa kokonaiselle organisaatiolle, ehkäpä rakentaen näin myös pohjaa innovaatioiden synnylle.

Näkemykseni mukaan taidekasvatuksen kentällä aikojen saatossa syntyneellä osaamisella on tarjota tulevaisuuden yrityselämälle erityisesti henkilöstökoulutuksen, organisaatioiden kehitysja muutostyön eri vaiheiden sekä työhyvinvoinnin ja mahdollisesti myös strategisen suunnittelun kehittämisen saralla uutta annettavaa. Taidekasvatukselle voimistuva yhteistyö yrityselämän kanssa tarjoaa kovin kiinnostavan laajenemisen alueen ja samalla myös rikastavan sisäisen keskustelun mahdollisuuden. Kaikkineen vahvistuva yhteistyö voisi edistää molemmin puolin tapahtuvien uudenlaisten toiminnan ja ajattelun mallien kehittelemistä, sekä toivon mukaan myös uusien, niin henkisten kuin taloudellisten innovaatioiden syntymistä.

\section{Lähteet}

von Branderburg. Cecilia (2006). Ars -06

Seminaari Kiasma. Painettu oheismateriaali / luento.

Juuti. Pauli ja Lindström. Kari (1995).

Postmoderni ajattelu ja organisaation syvällinen muutos. Työ ja ihminen. Tutkimusraportti 4. Työterveyslaitos. Johtamistaidon opisto.

Karhu. Mika (2003). Vallan Tunne. http:// www.mikakarhu.com/index.html (12.11.2005).

Sava. Inkeri (2005). http://virta.uiah.fi/kuvis/ taidkasvtutkmenetelmat/ (1.11.2005).

Schein. Edgar H. (1991). Organisaatiokulttuuri ja johtaminen. Weilin+Göös.

Toskala. Antero (2000). Itsetuntemus ja johtajuus II. Järjen ja tunteen uoropuhelua. ODECO. 